(i) (i) (i) (i) (i) (i) Di(i) (3) (3) (3) (3) (i) (3) ISSN: 2598-7607 e-ISSN: 2622-223X

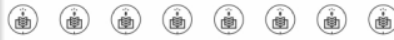

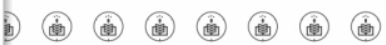

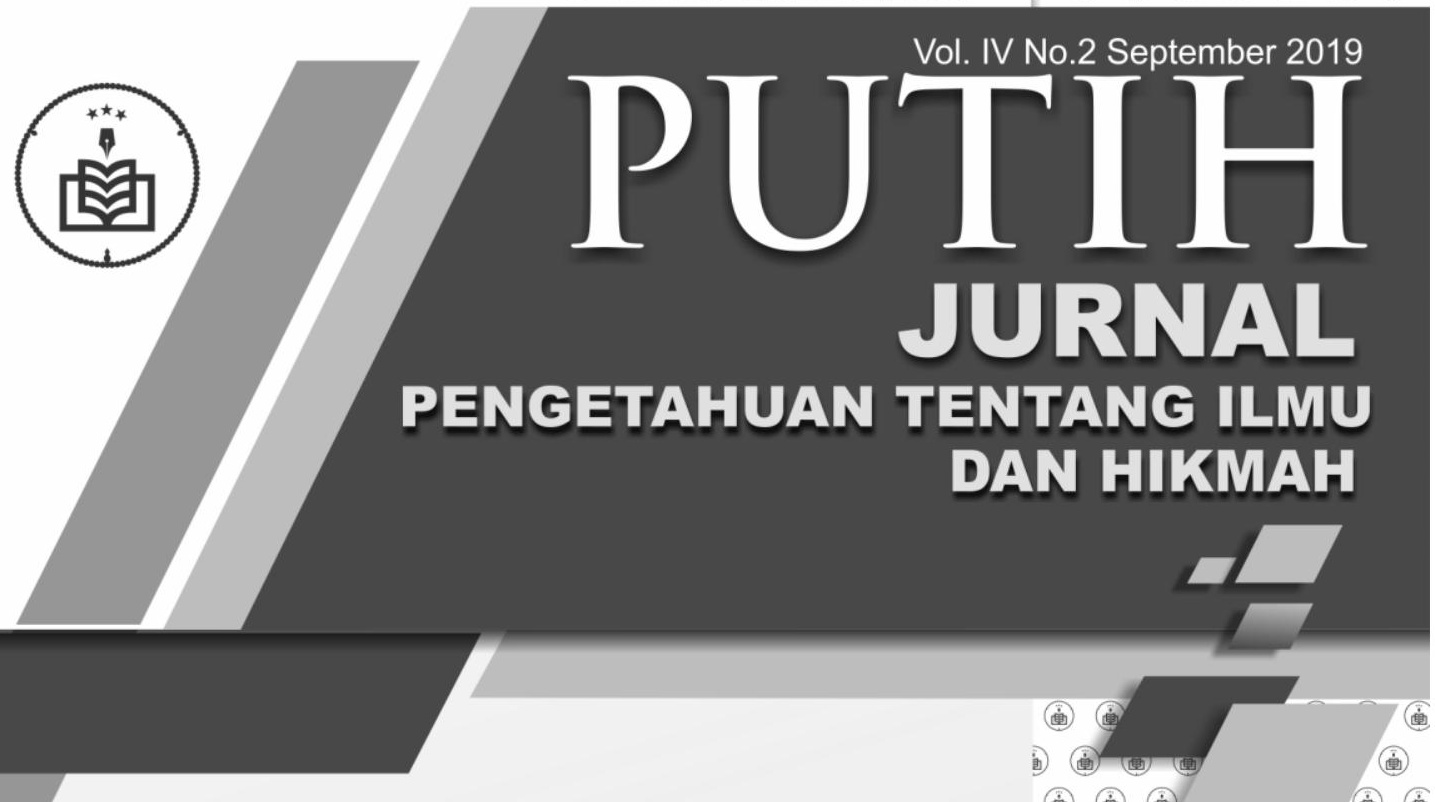

- PRINSIP-PRINSIP BUDAYA SEBAGAI SUMBER HUKUM ISLAM FathurRozi

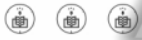

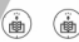
i

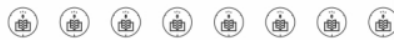

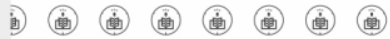

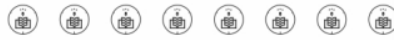

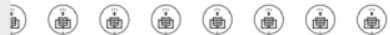

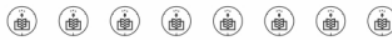

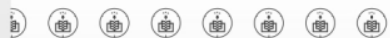

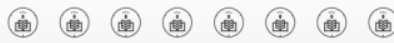

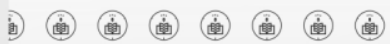

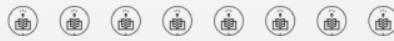

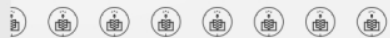

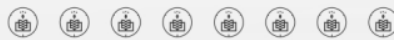

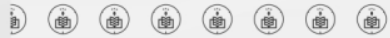

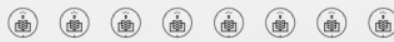

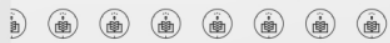

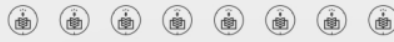

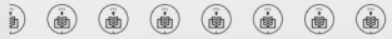

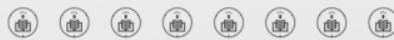
diterbitkan :

MA'HAD ALY

PONDOK PESANTREN ASSALAFI AL FITHRAH Surabaya

ib) (iii) (iii) (ii) (ii) (iii) (ii) (ii)

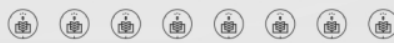
ib) (ii) (ii) (ii) (i) (i) (ii) (ii)

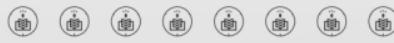
ii) (ii) (ii) (ii) (ii) (ii) (ii) (ii)

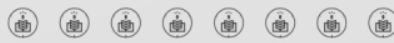

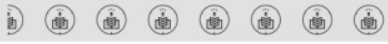




\section{Redaktur PUTIH \\ JURNAL PENGETAHUAN TENTANG ILMU DAN HIKMAH}

Ijin terbit

SK. Mudir Ma'had Aly No. 18/MAy-PAF/II/2018/SK

PEMBINA

Muhammad Musyafa'

Abdur Rosyid

Ahmad Syathori

PENGARAH

Fathur Rozi

PIMPINAN REDAKSI

Fathul Haris

DEWAN EDITOR

Achmad Imam Bashori

\section{ANGGOTA \\ Mustaqim \\ Samsul Arifin \\ Abdul Hadi}

Alamat Penyunting dan Surat Menyurat :

J1. Kedinding Lor 99 Surabaya
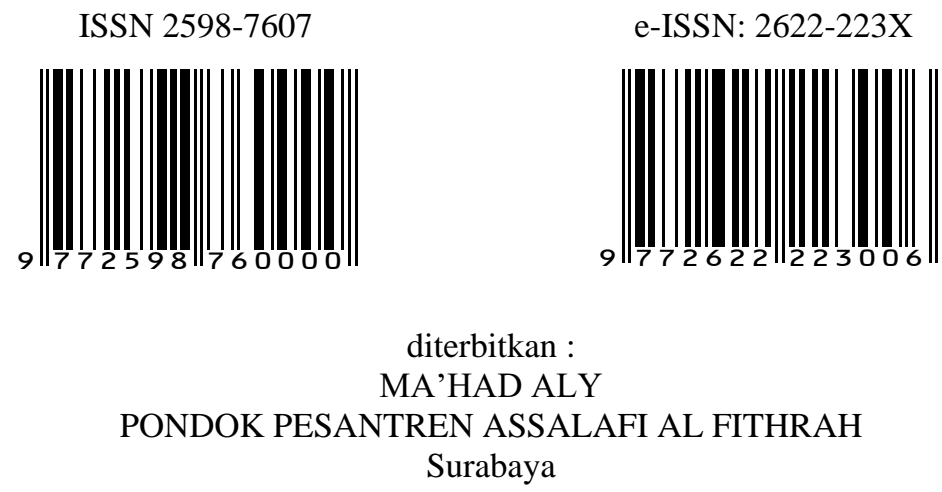


\section{$\underline{\text { Daftar Isi }}$}

- Daftar Isi

- Pedoman Transliterasi

- PRINSIP-PRINSIP BUDAYA SEBAGAI SUMBER HUKUM ISLAM

FathurRozi

- Jumlah Anak Ideal dalam Perspektif Hadis Muzamil

- Mengenal Tafsir Latā'if al-Isharāt Karya al-Qushayrī (Kerangka Metodologis dan Kecenderungan Ideologis) Kusroni

- MAHKOTA SINGGASANA DALAM ISTANA SHUFIYAH

Kajian Ruang Lingkup Maqomat Dan Ahwal (Pangkat, Derajat dan Kedudukan Para Shufi Di Sisi Allah Swt.)

Ahmad Syatori

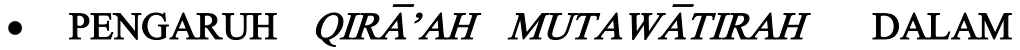
HUKUM FIQH

Abu Sari

- $A L-A S \overline{S I}:$ PENAFSIRAN AL QURAN DENGAN BAHASA ARAB

Fathul Haris 


\section{PEDOMAN TRANSLITERASI}

Berikut ini adalah skema transliterasi Arab-Indonesia yang ditetapkan dalam penulisan jurnal ini:

\begin{tabular}{|c|c|c|c|c|}
\hline $\mathrm{NO}$ & ARAB & INDONESIA & ARAB & INDONESIA \\
\hline 1 & 1 & 6 & $b$ & $\mathrm{t}$ \\
\hline 2 & ب & B & ظ & $\mathrm{Z}$ \\
\hline 3 & ت & $\mathrm{T}$ & $\varepsilon$ & ' \\
\hline 4 & ث & Th & $\dot{\varepsilon}$ & gh \\
\hline 5 & ج & $\mathrm{J}$ & ف & $\mathrm{F}$ \\
\hline 6 & $\tau$ & h & ق & Q \\
\hline 7 & $\dot{\tau}$ & $\mathrm{Kh}$ & s) & $\mathrm{K}$ \\
\hline 8 & د & D & J & $\mathrm{L}$ \\
\hline 9 & ذ & $\mathrm{Dh}$ & 5 & $\mathrm{M}$ \\
\hline 10 & $\jmath$ & $\mathrm{R}$ & ن & $\mathrm{N}$ \\
\hline 11 & j & $\mathrm{Z}$ & 9 & W \\
\hline 12 & س س & $\mathrm{S}$ & هـ & $\mathrm{H}$ \\
\hline 13 & ش & Sh & $s$ & , \\
\hline 14 & ص & $\mathrm{s}$ & ي & $\mathrm{y}$ \\
\hline 15 & ض & d & & \\
\hline
\end{tabular}

Untuk menunjukkan bunyi hidup panjang (madd) dengan cara menuliskan coretan horizontal di atas huruf $\bar{a}, \bar{i}$ dan $\bar{u}$ (أو، إِئ $\left.1 i_{6}\right)$. 


\title{
MAHKOTA SINGGASANA DALAM ISTANA SHUFIYAH
}

Kajian Ruang Lingkup Maqomat Dan Ahwal

(Pangkat, Derajat dan Kedudukan Para Shufi Di Sisi Allah Swt.)

\author{
Ahmad Syatori \\ Email: ahmad.syatori1972@gmail.com
}

\section{ABSTRAK}

Kajian ilmiah ini di dalamnya memuat ulasan tentang pendakianpendakian (suluk) para shufiyah dalam menempuh suatu penjalanan yang sangat jauh menuju suatu tempat kesempurnaan di sisi Allah Swt. yang disebut dengan maqomat. Dalam uraian pembahasannya mengkaji seputar hal-hal yang berkaitan dengan pangkat, derajat dan kedudukan (maqomat) serta perilaku batin (ahwal) para shufiyah dalam rangka shidqu al-tawajjuh menghadap Allah Swt. dengan penuh kesungguhan baik lahir maupun batin. Berangkat dan berawal dari sebuah perjalanan spiritual para shufi tersebut, maka kemudian jurnal ilmiah ini diberi judul dengan tajuk "Mahkota Singgasana Dalam Istana Shufiyah", yang maksudnya tiada lain adalah untuk menggambarkan tentang eksistensi dan kemuliaan-kemuliaan para shufiyah yang telah memiliki maqom (pangkat, derajat dan kedudukan) yang luhur dan berada dalam genangan kemakrifatan kepada Allah Swt. Mahkota adalah sebagai simbol penisbatan bagi seorang shufi yang telah mencapai suatu gelar atau pangkat mahkota kemakrifatan billah. Sedangkan singgasana digambarkan sebagai kedudukan atau derajat maqom tertentu bagi seorang shufi dalam maqomat yang ada. Adapun yang dimaksud dengan istana shufiyah tiada lain adalah puncak pendakian seorang shufi yang telah sampai (wushul) dan berada disuatu tempat yang luhur yakni kesempurnaan ma'rifat billah. Sungguh merupakan suatu kenikmatan, karunia dan anugerah yang sangat agung dan istimewa bagi hamba-hamba Allah, manakala mereka telah mampu mencapai dan meraih semua itu. Melalui berbagai proses dan latihan yang ketat (riyadloti nafs) serta disiplin diri yang kuat (mujahadati nafs) dalam rangka membentuk jiwa dan hati yang bersih, suci dan kosong (takholli) dari sikap dan 
perilaku yang buruk dan tercela (akhlak madzmumah) serta menghiasi (tahalli) diri dengan sikap dan perilaku yang baik dan terpuji (akhlak mahmudah). Maka kemudian mereka sampai dan tersampaikan (wushul), tunduk dan bersimpuh di hadapan kekasihnya yang sejati Allah Swt. untuk menerima berbagai sirrirahasia, hikmah dan hakikat (tajalli) yang luhur dari Dzat Yang Maha Agung dan Sempurna (Allah Swt.).

Kata kunci: maqom, ahwal, ma'rifat dan shufi

\section{Pendahuluan}

Tasawuf merupakan salah satu fenomena dalam Islam yang memusatkan perhatian pada pembersihan aspek ruhani manusia, yang selanjutnya menimbulkan akhlak mulia. Melalui tasawuf ini seseorang dapat mengetahui tentang cara-cara melakukan pembersihan diri serta mengamalkan secara benar. banyak pengertian tasawuf yang dirumuskan oleh ulama tasawuf, tetapi tidak mencakup pengertian tasawuf secara menyeluruh. defenisi tasawuf yang dirumuskan oleh ulama tasawuf, tetapi tidak mencakup pengertian tasawuf secara menyeluruh.

Tinjauan analitis terhadap tasawuf menunjukkan bahwa para shufi dengan berbagai aliran yang dianutnya memiliki suatu konsepsi tentang jalan (thariqat) menuju Allah. Jalan ini dimulai dengan latihan-latihan ruhaniah (riyadah), lalu secara bertahap menempuh berbagai fase, yang dikenal dengan maqom (tingkatan) dan hal (keadaan), dan berakhir dengan mengenal (ma'rifat) kepada Allah. Tingkat pengenalan (ma'rifat) menjadi jargon yang umumnya banyak dikejar oleh para shufi. Kerangka sikap dan perilaku shufi diwujudkan melalui amalan dan metode tertentu yang disebut 
thariqat, atau jalan untuk menemukan pengenalan (ma'rifat) kepada Allah Swt. Lingkup perjalanan menuju Allah untuk memperoleh pengenalan (ma'rifat) yang berlaku di kalangan shufi sering disebut sebagai sebuah kerangka 'Irfani.

Perjalanan menuju Allah merupakan metode pengenalan (ma'rifat) secara rasa (ruhaniah) yang benar terhadap Allah. Manusia tidak akan tidak akan tahu banyak mengenai penciptanya apabila belum melakukan perjalanan menuju kehadirat Allah Swt. walaupun ia adalah orang yang beriman secara aqliyah. Hal ini karena adanya perbedaan yang dalam antara iman secara aqliyah atau logis-teoritis (Al-Iman Alaqli An-nazhari) dan iman secara rasa (al-iman Asy-syu'uri Ad-dzauqi).

Lingkup 'Irfani tidak dapat dicapai dengan mudah atau secara spontanitas, tetapi melalui proses yang panjang. Proses yang dimaksud adalah maqom-maqom (tingkatan atau stasiun) dan ahwal (jama' dari hal). Dua persoalan ini harus dilewati oleh orang yang berjalan menuju Allah.

Namun perlu dicatat, maqom dan hal tidak dapat dipisahkan. Keduanya ibarat dua sisi dalam satu mata uang. Keterkaitan antar keduanya dapat dilihat dalam kenyataan bahwa maqom menjadi prasyarat menuju kehadirat Allah Swt. dalam maqom akan ditemukan kehadiran hal. Hal yang telah ditemukan dalam maqom akan mengantarkan seseorang untuk mendaki maqom-maqom selanjutnya. Untuk itu maka penulis akan berusaha untuk mengkaji dan membahas tentang maqomat dan ahwal dalam kajian ilmu tasawuf. 


\section{Maqomat}

Secara harfiah, maqomat merupakan jamak dari kata maqom yang berarti tempat berpijak atau pangkat mulia. Dalam Bahasa Inggris maqomat dikenal dengan istilah stages yang berarti tangga. Sedangkan dalam ilmu Tasawuf, maqomat berarti kedudukan hamba dalam pandangan Allah Swt. berdasarkan apa yang telah diupayakan dan diusahakannya, baik melalui riyadhah, ibadah, maupun mujahadah. Di samping itu, maqomat berarti jalan panjang atau fase-fase yang harus ditempuh oleh seorang shufi untuk berada sedekat mungkin dengan Allah. Maqom dilalui seorang hamba melalui usaha yang sungguh-sungguh dalam melakukan sejumlah kewajiban yang harus ditempuh dalam jangka waktu tertentu. Seorang hamba tidak akan mencapai maqom berikutnya sebelum menyempurnakan maqom sebelumnya. ${ }^{1}$

Tentang berapa jumlah tangga atau maqomat yang harus ditempuh oleh seorang shufi untuk sampai menuju Allah Swt., di kalangan para shufi tidak sama pendapatnya. Muhammad alKalabazy dalam kitabnya al-Ta'arruf li Mazhab ahl al-Tasawwuf, sebagaimana dikutip oleh Harun Nasution misalnya, ia mengatakan bahwa maqomat itu jumlahnya ada sepuluh, yaitu al-taubah, alzuhud, al-shabr, al-faqr, al-tawadlu', al-taqwa, al-tawakkal, al-ridla, al-mahabbah dan al-ma'rifah.

Sementara itu Abu Nasr al-Sarraj al-Tusi dalam kitab al-

1 Tim Penyusun MKD IAIN Sunan Ampel, Akhlak Tasawuf, (Surabaya: IAIN SA Press, 2011), h.243 
Luma'menyebutkan jumlah maqamat hanya tujuh, yaitu al-taubah, al-wara', al-zuhud, al-faqr, al-tawakkal dan al-ridla. Dalam pada itu Imam al-Ghazali dalam kitabnya Ihya' Ulum al-Din mengatakan bahwa maqamat itu ada delapan, yaitu al-taubah, al-shabr, al-zuhud, al-tawakkal, al-mahabbah, al-ma'rifah, dan al-ridla.

Nukilan-nukilan atau kutipan tersebut menunjukkan atas keadaan variasi penyebutan maqomat yang berbeda-beda, namun juga ada maqomat yang oleh mereka sepakati sama, yaitu al-taubah, al-zuhud, al-wara, al-faqr, al-shabr, al-tawakkal dan al-ridla. Sedangkan al-tawaddlu, al-mahabbah, dan al-ma'rifah oleh mereka tidak disepakati sebagai maqamat. Terhadap tiga istilah yang disebut terakhir itu (al-tawaddlu, al-mahabbah dan al-ma'rifah) terkadang para ahli tasawuf menyebutnya sebagai maqomat, dan terkadang menyebutnya sebagai hal dan ittihad (tercapainya kesatuan wujud ruhaniah dengan Allah). Untuk itu dalam uraian ini, maqomat yang akan dijelaskan lebih lanjut adalah maqomat yang disepakati oleh mereka, yaitu al-taubah, al-zuhud, al-wara', al-faqr, al-shabr, al-tawakkal, dan al-ridla. Penjelasan atas masing-masing istilah tersebut dapat dikemukakan sebagai berikut: ${ }^{1}$

\section{Taubat}

Taubat berasal dari Bahasa Arab taba-yatubu-taubatan yang berarti "kembali" dan "penyelesalan". Sedangkan pengertian taubat bagi kalangan shufi adalah memohon ampun atas segala dosa

${ }^{1}$ Abuddin Nata, Akhlak Tasawuf, (Jakarta: Rajawali Pers, 2011), h.193-194 
yang disertai dengan penyesalan dan berjanji dengan sungguhsungguh untuk tidak mengulangi perbuatan dosa tersebut dan dibarengi dengan melakukan kebajikan yang dianjurkan oleh Allah.

Taubat menurut Dzun Nun al-Misri dibedakan menjadi tiga tingkatan: (1) orang yang bertaubat dari dosa dan keburukan, (2) orang yang bertaubat dari kelalaian mengingat Allah dan (3) orang yang bertaubat karena memandang kebaikan dan ketaatannya. Dari ketiga tingkatan taubat tersebut, yang dimaksud sebagai maqam dalam tasawuf adalah upaya taubat, karena merasakan kenikmatan batin.

Bagi orang awam, taubat dilakukan dengan membaca astagfirullah wa atubu ilaihi. Sedangkan bagi orang khawash taubat dilakukan dengan riyadhah dan mujahadah dalam rangka membuka hijab yang membatasi dirinya dengan Allah swt. Taubat ini dilakukan para shufi hingga mampu menggapai maqam yang lebih tinggi.

Lain halnya dengan Ibnu Taimiyah. Ia membedakan taubat menjadi dua: taubat wajib dan taubat sunnah. Taubat wajib adalah taubat karena menyesali perbuatan meninggalkan perkara-perkara wajib, atau menyesal karena melakukan perkara-perkara haram. Sedangkan taubat sunnah adalah taubat karena menyesali perbuatan meninggalkan perkara-perkara sunnah, atau karena menyesali perbuatan melakukan perkara-perkara makruh. Berkaitan dengan dua macam taubat ini, Ibnu Taimiyah menjelaskan tingkatan atau derajat orang yang bertaubat menjadi dua. Pertama, al-abrar al- 
muqtashidun (orang-orang yang berbakti lagi pertengahan), yaitu orang-orang yang melakukan jenis taubat yang pertama, yaitu taubat wajib. Kedua, as-sabiqun al-awwalun. Mereka adalah orang yang melakukan jenis taubat wajib dan taubat sunnah. ${ }^{1}$

Taubat seperti dijelaskan oleh Imam Ghazali dalam kitabnya "Ihya ulumuddin" adalah sebuah makna yang terdiri dari tiga unsur: ilmu, hal dan amal. Ilmu adalah unsur yang pertama, kemudian yang kedua hal, dan ketiga amal. Ia berkata: yang pertama mewajibkan yang kedua, dan yang kedua mewajibkan yang ketiga. Berlangsung sesuai dengan hukum (ketentuan) Allah Swt. yang berlangsung dalam kerajaan dan malakut-Nya.

Ia berkata: "Sedangkan ilmu adalah, mengetahui besarnya bahaya dosa, dan ia adalah penghalang antara hamba dan seluruh yang ia senangi. Jika ia telah mengetahui itu dengan yakin dan sepenuh hati, pengetahuannya itu akan berpengaruh dalam hatinya dan ia merasakan kepedihan karena kehilangan yang dia cintai. Karena hati, ketika ia merasakan hilangnya yang dia cintai, ia akan merasakan kepedihan, dan jika kehilangan itu diakibatkan oleh perbuatannya, niscaya ia akan menyesali perbuatannya itu. Dan perasaan pedih kehilangan yang dia cintai itu dinamakan penyesalan. Jika perasaan pedih itu demikian kuat berpengaruh dalam hatinya dan menguasai hatinya, maka perasaan itu akan mendorong timbulnya perasaan lain, yaitu tekad dan kemauan untuk mengerjakan apa yang seharusnya pada saat ini, kemarin dan akan

${ }^{1}$ Tim penyusun MKD IAIN Sunan Ampel, Akhlak..., h.244-245 
datang. Tindakan yang ia lakukan saat ini adalah meninggalkan dosa yang menyelimutinya, dan terhadap masa depannya adalah dengan bertekad untuk meninggalkan dosa yang mengakibatkannya kehilangan yang dia cintai hingga sepanjang masa. Sedangkan masa lalunya adalah dengan menebus apa yang ia lakukan sebelumnya, jika dapat ditebus, atau menggantinya.

Pertama adalah ilmu. Dialah pangkal pertama seluruh kebaikan ini. Yang aku maksudkan dengan ilmu ini adalah keimanan dan keyakinan. Karena iman bermakna pembenaran bahwa dosa adalah racun yang menghancurkan. Sedangkan yakin adalah penegasan pembenaran ini, tidak meragukannya serta memenuhi hatinya. Maka cahaya iman dalam hati ini ketika bersinar akan membuahkan api penyesalan, sehingga hati merasakan kepedihan. Karena dengan cahaya iman itu ia dapat melihat bahwa saat ini, karena dosanya itu, ia terhalang dari yang dia cintai. Seperti orang yang diterangi cahaya matahari, ketika ia berada dalam kegelapan, maka cahaya itu menghilangkan penghalang penglihatannya sehingga ia dapat melihat yang dia cintai. Dan ketika ia menyadari ia hampir binasa, maka cahaya cinta dalam hatinya bergejolak, dan api ini membangkitkan kekuatannya untuk menyelamatkan dirinya serta mengejar yang dia cintai itu.

Ilmu dan penyesalan, serta tekad untuk meninggalkan perbuatan dosa saat ini dan masa akan datang, serta berusaha menutupi perbuatan masa lalu mempunyai tiga makna yang berkaitan dengan pencapaiannya itu. Secara keseluruhan dinamakan 
taubat. Banyak pula taubat itu disebut dengan makna penyesalan saja. Ilmu akan dosa itu dijadikan sebagai permulaan, sedangkan meninggalkan perbuatan dosa itu sebagai buah dan konsekwensi dari ilmu itu. Dari itu dapat dipahami sabda Rasulullah Saw. bahwa : " Penyesalan itu adalah taubat". Hafizh al 'Iraqi dalam takhrij haditshadits Ihya Ulumuddin berkata: hadits ini ditakhrijkan oleh Ibnu Majah, Ibnu Hibban, dan al Hakim. Serta ia mensahihkan sanadnya dari hadits Ibnu Mas'ud. Dan diriwayakan pula oleh Ibnu Hibban dan Al Hakim dari hadits Anas r.a. dan ia berkata: hadits ini sahih atas syarat Bukhari dan Muslim), karena penyesalan itu dapat terjadi dari ilmu yang mewajibkan serta membuahkan penyesalan itu, dan tekad untuk meninggalkan dosa sebagai konsekwensinya. Maka penyesalan itu dipelihara dengan dua cabangnya, yaitu buahnya dan apa yang membuahkannya. ${ }^{1}$

Berkaitan dengan maqam taubat, dalam al-Qur'an terdapat banyak ayat yang menjelaskan masalah ini, di antaranya adalah ayat yang berbunyi:

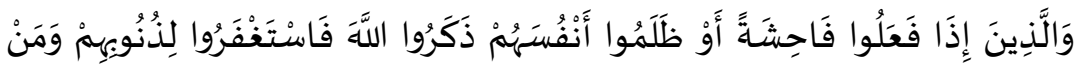

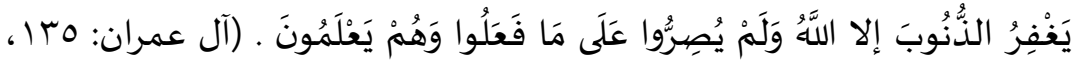
( I r

Dan (juga) orang-orang yang apabila mengerjakan perbuatan keji atau menganiaya diri sendiri, mereka ingat akan Allah, lalu memohon ampun terhadap dosa-dosa mereka dan siapa lagi yang dapat mengampuni dosa selain dari pada Allah?

\footnotetext{
$1 \quad$ http://sufiroad.blogspot.com/2011/12/taubat-menurut-imam-
} ghazali.html di akses tgl 21 februari 2013 
Dan mereka tidak meneruskan perbuatan kejinya itu, sedang mereka mengetahui.(Ali Imron: 135).

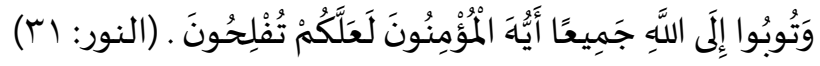

...dan bertaubatlah kamu sekalian kepada Allah, hai orangorang yang beriman supaya kamu beruntung.(An-Nur: 31$)^{1}$

\section{Zuhud}

Secara etimologis, zuhud berarti raghaba 'an syai'in wa tarakahu, artinya tidak tertarik terhadap sesuatu dan meninggalkannya. Zuhud fiddunya, berarti mengosongkan diri dari kesenangan dunia untuk ibadah. ${ }^{2}$

Menurut pandangan orang-orang shufi, dunia dan segala kemewahan, serta kelezatannya adalah sumber kemaksiatan dan penyebab terjadinya perbuatan-perbuatan dosa. Oleh karena itu, seorang pemula atau calon shufi harus terlebih dahulu menjadi zahid. Sikap zuhud ini erat hubungannya dengan taubah, sebab taubah tidak akan berhasil apabila hati dan keinginannya masih terkait kepada kesenangan duniawi.

Mengenai pengertian zuhud ini terdapat berbagai variasi. AlJunaidi berkata: "Zuhud ialah keadaan jiwa yang kosong dari rasa memiliki dan ambisi menguasai." Ali bin Abi Talib ketika ditanya tentang zuhud, ia menjawab: "Zuhud berarti tidak peduli, siapa yang memanfaatkan benda-benda duniawi ini, baik seorang yang beriman atau tidak." Dan Syaikh al-Syibli ketika ditanya tentang zuhud, lalu

${ }^{1}$ Tim penyusun MKD IAIN Sunan Ampel, Akhlak..., h.245-246

2 Amin Syukur, Zuhud di Abad Modern, (Yogyakarta: Pustaka Pelajar, 2004), h.1 
beliau berkata: "Dalam kenyataannya zuhud itu tidak ada. Jika seseorang bersikap zuhud pada sesuatu yang tidak menjadi miliknya, maka itu bukan zuhud, dan jika seseorang bersikap zuhud pada sesuatu yang menjadi miliknya, bagaimana bisa dikatakan bahwa ituzuhd, sedangkan sesuatu itu masih ada padanya dan dia masih memilikinya? Zuhud berarti menahan hawa nafsu, bermurah hati dan berbuat kebaikan." Hal ini seakan-akan mengisyaratkan bahwa dia mengartikan zuhud sebagai tindakan meninggalkan sesuatu yang tidak menjadi miliknya. Dan jika sesuatu itu tidak menjadi milik seseorang, maka tidak dapat dikatakan bahwa orang itu meninggalkannya, sebab sesuatu memang telah tertinggalkan, sedangkan jika sesuatu itu menjadi milik seseorang, maka tidak mungkin orang itu meninggalkannya. Namun, betapapun bervariasinya pengertian yang diberikan, tekanan utama pada sikap zuhud adalah mengurangi keinginan terhadap kehidupan duniawi.

Untuk lebih memperjelas pengertian dan rumusan zuhud di atas, tentu masih dirasa perlu untuk mencantumkan beberapa pengertian lagi. Zuhud menurut Ibn Qudamah al-Muqaddasi ialah "pengalihan keinginan dari sesuatu kepada sesuatu yang lebih baik." Menurut Imam Al-Ghazali, "zuhud ialah mengurangi keinginan kepada dunia dan menjauh daripadanya dengan penuh kesadaran dan dalam hal yang mungkin dilakukan.” Imam al-Qusyairi mengatakan, "zuhud ialah tidak merasa bangga dengan kemewahan dunia yang telah ada di tangannya dan tidak merasa bersedih dengan hilangnya 
kemewahan tadi dari tangannya. ${ }^{1}$

Berkaitan dengan konsep zuhud, dalam al-Qur'an terdapat ayat yang menjelaskan hal itu, di antaranya:

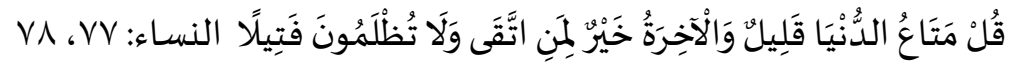

Katakanlah: "Kesenangan di dunia ini hanya sebentar dan akhirat itu lebih baik untuk orang-orang yang bertakwa, dan kamu tidak akan dianiaya sedikitpun. (An-Nisa': 77).

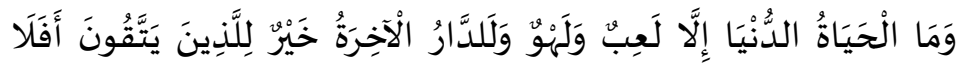

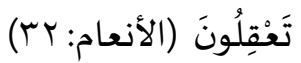

Dan tiadalah kehidupan dunia ini, selain dari main-main dan senda gurau belaka. dan sungguh kampung akhirat itu lebih baik bagi orang-orang yang bertaqwa. Maka tidakkah kamu memahaminya? (Al-An'am: 32).

Ayat-ayat di atas secara singkat menjelaskan bahwa kehidupan dunia yang kita rasakan hanyalah sesaat dan suatu saat akan lenyap dan musnah dalam seketika, dibandingkan dengan kehidupan akhirat yaitu kehidupan yang ditempuh sesudah kita mati merupakan alam yang kekal dan abadi dan merupakan kehidupan yang lebih baik daripada kehidupan dunia.

Zuhud berdasarkan maksudnya dibagi menjadi tiga tingkatan. Pertama, zuhud menjauhkan dunia agar terhindar dari hukuman akhirat. Kedua, zuhud menjauhi dunia dengan mengharap imbalan di akhirat. Ketiga, zuhud meninggalkan kesenangan dunia bukan karena berharap atau takut, akan tetapi karena kecintaan

1 Asmaran As, Pengantar Studi Tasawuf, (Jakarta: PT Raja Grafindo Persada, 2002), h.114-115 
terhadap Allah semata. Pada tingkatan ketiga inilah yang mampu membukakan tabir antara seorang hamba dan Allah.

Selain ketiga zuhud tersebut, al-Ghazali juga mengklasifikasikan zuhud menjadi beberapa tingkatan, yaitu:

1. Zuhud yang dikaitkan dengan jiwa orang yang berzuhud. Tingkatan ini dibedakan kembali menjadi tiga bagian berdasarkan kuat lemahnya zuhud, yaitu:

a. As-sufla, yaitu derajat zuhud yang paling rendah, dimana orang meninggalkan kemewahan dunia tetapi sebenarnya hatinya masih cenderung dan menginginkannya.

b. Derajat zuhud orang yang meninggalkan kemewahan dunia secara sukarela, karena ia melihat dunia sebagai kehinaan.

c. A-'Ulya, yaitu derajat yang paling tinggi. Maksudnya, di sini adalah menjauhi kemewahan dunia secara sukarela, karena ia melihat dunia tidak mempunyai nilai apa-apa dan tidak sepadan dengan sesuatu apapun.

2. Zuhud yang dikaitkan dengan sesuatu yang dicintai. Zuhud ini dibagi menjadi tiga bagian, yaitu:

a. Zuhudnya orang takut, dimana seorang hamba melakukan zuhud dikarenakan takut akan siksa neraka, azab kubur dan lain-lain.

b. Zuhud orang yang mengharapkan pahala, nikmat Allah dan kelezatan yang telah dijanjikan di dalam surga.

c. Derajat yang tertinggi, yaitu zuhudnya para arif di mana zuhud mereka bukan dikarenakan suatu apapun selain Allah, 
tetapi hanya ingin berjumpa dengan Allah.

3. Zuhud yang dikaitkan dengan sesuatu yang harus ditinggalkan. Tingkatan ini dibagi menjadi:

a. Meninggalkan sesuatu selain Allah.

b. Meninggalkan segala sesuatu yang dikarenakan nafsu, seperti marah, sombong, pangkat, harta, dan lain-lain.

4. Zuhud dengan meninggalkan harta, pangkat dan segala sesuatu yang menyebabkan seseorang mendapatkannya. Meninggalkan dirham, pangkat, dan segala kesenangan dunia. ${ }^{1}$

\section{Sabar}

Sabar, secara harfiah, berarti tabah hati. Secara terminologi, sabar adalah suatu keadaan jiwa yang kokoh, stabil dan konsekuen dalam pendirian. Sedangkan menurut pandangan Dzun Nun al-Misri, sabar berarti menjauhkan diri dari hal-hal yang bertentangan dengan kehendak Allah, tetap tenang ketika mendapat cobaan dan menampakkan sikap cukup, walaupun sebenarnya berada dalam kefakiran. Berdasarkan pengertian di atas, maka sabar erat hubungannya dengan pengendalian diri, pengendalian sikap dan pengendalian emosi. Oleh sebab itu, sikap sabar tidak bisa terwujud begitu saja, akan tetapi harus melalui latihan yang sungguhsungguh. ${ }^{2}$

Sabar, menurut Al-Ghazali, jika dipandang sebagai

${ }^{1}$ Tim penyusun MKD IAIN Sunan Ampel, Akhlak..., h.248-250

${ }^{2}$ Ibid, h. 250-251 
pengekangan tuntutan nafsu dan amarah, dinamakan sebagai kesabaran jiwa (ash-shabr an-nafs), sedangkan menahan terhadap penyakit fisik, disebut sebagai sabar badani (ash-shabr al-badani). Kesabaran jiwa sangat dibutuhkan dalam berbagai aspek. Misalnya, untuk menahan nafsu makan dan seks yang berlebihan. ${ }^{1}$

\section{Wara'}

Wara', secara harfiah, berarti saleh, menjauhkan diri dari perbuatan dosa atau maksiat. Sedangkan pengertian wara' dalam pandangan shufi adalah meninggalkan segala sesuatu yang tidak jelas hukumnya, baik yang menyangkut makanan, pakaian, maupun persoalan lainnya. Menurut Qamar Kailani yang dikutip oleh Rivay A. Siregar, wara' dibagi menjadi dua: wara' lahiriyah dan wara' batiniyah.Wara' lahiriyah adalah tidak mempergunakan segala yang masih diragukan dan meninggalkan kemewahan, sedangkan wara' batiniyah adalah tidak menempatkan atau mengisi hati kecuali dengan mengingat Allah. Dalam kitab Al-Luma' dijelaskan bahwa orang-orang wara' dibagi menjadi tiga tingkatan. Pertama, wara' orang yang menjauhkan diri dari syubhat. Kedua,wara' orang yang menjauhkan diri dari sesuatu yang menjadi keraguan hati dan ganjalan di dada. Ketiga, wara' orang arif yang sanggup menghayati dengan hati nurani. ${ }^{2}$

${ }^{1}$ Rosibon Anwar dan Mukhtar Solihin, Ilmu Tasawuf, (Bandung: Pustaka Setia, 2004),h.72

${ }^{2}$ Tim penyusun MKD IAIN Sunan Ampel, Akhlak..., h.252-253 


\section{Faqr}

Secara harfiah fakir biasanya diartikan sebagai orang yang berhajat, butuh atau orang miskin. Sedangkan dalam pandangan shufi fakir adalah tidak meminta lebih dari apa yang telah ada pada diri kita. ${ }^{1}$ Tidak meminta rezeki kecuali hanya untuk menjalankan kewajiban-kewajiban. Tidak meminta sungguhpun tak ada pada diri kita, kalau diberi diterima. Tidak meminta tetapi tidak menolak. ${ }^{2}$

\section{Tawakkal}

Secara harfiah tawakkal berarti menyerahkan diri. Menurut Sahal bin Abdullah bahwa awalnya tawakkal adalah apabila seorang hamba di hadapan Allah seperti bangkai di hadapan orang yang memandikannya, ia mengikuti semaunya yang memandikan, tidak dapat bergerak dan bertindak. Hamdun al-Qashshar mengatakan tawakkal adalah berpegang teguh pada Allah.

Al-Qusyairi lebih lanjut mengatakan bahwa tawakkal tempatnya di dalam hati, dan timbulnya gerak dalam perbuatan tidak mengubah tawakkal yang terdapat dalam hati itu. Hal itu terjadi setelah hamba meyakini bahwa segala ketentuan hanya didasarkan pada ketentuan Allah. Mereka menganggap jika menghadapi kesulitan maka yang demikian itu sebenarnya takdir

\footnotetext{
1 Amin Syukur, Tasawuf Kontekstual Solusi Problem Manusia Modern,(Yogyakarta: Pustaka Pelajar, 2003), h.30

2 Fauzan,"Maqamat dan Ahwal', dalamhttp://makalah majannaii. blogspot.com/2012/04/maqamat-dan-ahwal.html diakses tgl 24/11/2012 pukul 23.08
} 
Allah.

Pengertian tawakkal yang demikian itu sejalan pula dengan yang dikemukakan Harun Nasution. Ia mengatakan tawakkal adalah menyerahkan diri kepada qada dan keputusan Allah. Selamanya dalam keadaan tenteram, jika mendapat pemberian berterima kasih, jika mendapat apa-apa bersikap sabar dan menyerah kepada qada dan qadar Tuhan. Tidak memikirkan hari esok, cukup dengan apa yang ada untuk hari ini. Tidak mau makan, jika ada orang lain yang lebih berhajat pada makanan tersebut daripada dirinya. Percaya kepada janji Allah. Menyerah kepada Allah dengan Allah dan karena Allah. ${ }^{1}$

\section{Ridha}

Ridha, secara harfiah, berarti rela, senang dan suka. Sedangkan pengertiannya secara umum adalah tidak menentang qadha dan qadar Allah, menerima qadha dan qadar dengan hati senang. Mengeluarkan perasaan benci dari hati sehingga yang tinggal di dalamnya hanya perasaan senang dan gembira. Merasa senang menerima malapetaka sebagaimana merasa senang menerima nikmat. Tidak meminta surga dari Allah dan tidak meminta dijauhkan dari neraka. Sikap ridha ini merupakan kelanjutan rasa cinta atau perpaduan dari mahabbah dan sabar. Rasa cinta yang diperkuat dengan ketabahan akan menimbulkan kelapangan hati dan kesediaan yang tulus untuk berkorban dan berbuat apa saja yang

${ }^{1}$ Abuddin Nata, Akhlak Tasawuf, (Jakarta: Rajawali Pers, 2011), h.202 
diperintahkan oleh Allah Swt.

Menurut Abdullah bin Khafif, ridha dibagi menjadi dua macam: ridha dengan Allah dan ridha terhadap apa yang datang dari Allah. Ridha dengan Allah berarti bahwa seorang hamba rela terhadap Allah sebagai pengatur jagad raya seisinya, sedangkan ridha terhadap apa yang datang dari Allah yaitu rela terhadap apa saja yang telah menjadi ketetapan Allah Swt. ${ }^{1}$

\section{Mahabbah}

Mahabbah berasal dari kata ahabba-yuhibbu-mahabbatan yang berarti mencintai secara mendalam. Mahabbah pada tingkatan selanjutnya dapat diartikan suatu usaha sungguhsungguh dari seseorang untuk mencapai tingkat ruhaniah tertinggi dengan terwujudnya kecintaan yang sangat mendalam kepada Allah Swt. Berkaitan dengan konsep mahabbah, Rabi'ah al-Adawiyah adalah merupakan orang pertama peletak dasar mahabbah ini. Mahabbah dalam pandangan Rabi'ah adalah cinta abadi kepada Allah yang melebihi cinta kepada siapa pun dan apapun. Cinta abadi yang tidak takut kepada apa saja, bahkan neraka sekalipun. Sebagaimana dalam syair Rabi'ah yang berbunyi:

"Kujadikan Engkau teman percakapan hatiku, Tubuh kasarku biar bercakap dengan insani, Jasadku biar bercengkrama tulangku, Isi hatiku tetap pada-Mu jua."

Menurut Rabi'ah al-Adawiyah, Allah adalah salah satu yang

${ }^{1}$ Tim penyusun MKD IAIN Sunan Ampel, Akhlak..., h.257-258 
seharusnya dicintai dan Dialah tujuan akhir dalam pencarian cinta yang abadi. Untuk menggapai kecintaan Ilahi, maka seorang sufi harus melatih dirinya untuk mencintai segala keindahan alam seisinya. Karena keindahan adalah ciri dari zat yang dicintai. Bagi Rabi'ah, rasa cinta kepada Allah menjadi salah satu motivasi dalam setiap perilakunya dan sekaligus merupakan tujuan pengabdiannya kepada Allah. Rabi'ah al-Adawiyah mengatakan; "Aku mencintai$\mathrm{Mu}$ dengan dua dorongan cinta, cinta-rindu, karena aku menginginkan-Nya dan cinta karena Engkau patut mendapatkannya. Cinta-rindu menenggelamkan diriku untuk selalu mengingat dan menyebut-Mu. Cinta rindu membuatku lupa dengan orang yang selain yang kucinta, sedangkan cinta karena Engkau pantas dicintai adalah keterbukaan-Mu dari tirai penghalang sehingga aku dapat melihat-Mu dengan terang benderang. Aku tak pantas mendapatkan pujian untuk cinta pertama dan cinta kedua, tetapi segala puji untukMu belaka pada cinta pertama dan cinta kedua.

Dalam pandangan Ath-Thusi, mahabbah dibagi menjadi beberapa tingkatan. Pertama, mahabbah al-'ammah, yaitu cinta yang timbul dari belas kasihan dan kebaikan Allah kepada hamba-Nya. Kedua, hubb ash-shadiqin wa al-muttaqin, yaitu cinta yang timbul dari pandangan hati sanubari terhadap kebesaran, keagungan, kemahakuasaan, ilmu dan kekayaan Allah Swt. Ketiga, mahabbah para ash-shidiqin wa al-'arifin, yaitu mahabbah yang timbul dari penglihatan dan ma'rifatnya para shufi terhadap kekalnya kecintaan Allah yang tanpa 'illat.Adapun tanda-tanda cinta seorang hamba 
terhadap Allah di antaranya adalah:

1. Senang bertemu dengan kekasihnya (Allah) dengan cara saling membuka rahasia dan saling melihat satu sama lain.

2. Melakukan segala hal yang disenangi kekasihnya. Atas nama cinta kepada Allah, rela menjalankan kewajiban yang diperintahkan.

3. Senantiasa berzikir menyebut nama-Nya.

4. Merasa tenang dan damai tatkala bermunajat dengan Allah dan membaca kitab-Nya.

5. Tidak merasa gundah jika kelihangan sesuatu selain Allah dan merasa gundah jika waktunya terlewatkan tanpa mengingat Allah.

6. Merasa nikmat saat menjalankan perintah Allah dan tidak menganggap perintah itu sebagai beban.

7. Menyanyangi semua hamba Allah, berperilaku tegas kepada semua musuh Allah. ${ }^{1}$

\section{Ma'rifat}

Ma'rifat berasal dari kata 'arafa-ya'rifu-irfan-ma'rifat yang berarti pengetahuan atau pengalaman. Ma'rifat dapat pula berarti pengetahuan rahasia hakikat agama, yaitu ilmu yang lebih tinggi daripada ilmu yang didapat pada umumnya, dan merupakan pengetahuan yang objeknya bukan hal-hal yang bersifat zhahir, tetapi bersifat batin, yaitu pengetahuan mengenai rahasia-rahasia

${ }^{1}$ Ibid, h. 258-260 
Allah melalui pancaran cahaya Ilahi. Adapun alat untuk memperoleh ma'rifat bersandar pada sir, qalb, dan ruh. Qalb yang telah suci akan dipancari cahaya Ilahi dan akan dapat mengetahui segala rahasia Tuhan. Pada saat itulah, seorang sufi sampai pada tingkatan ma'rifat. Dengan demikian, ma'rifat berhubungan dengan nur Ilahi dan berkaitan dengan nur Ilahi. Dalam al-Qur'an terdapat beberapa kata nur yang dihubungkan dengan Allah. Di antaranya adalah:

Ma'rifat dalam pandangan al-Ghazali adalah mengetahui rahasia Allah tentang segala yang ada. Al-Ghazali dalam Ihya' 'Ulum ad-Din membedakan jalan pengetahuan sampai kepada Tuhan antara orang awam, ulama dan sufi. Bagi orang awam, keyakinan akan pengetahuan tentang Allah dibangun atas dasar taqlid, yaitu hanya mengikuti perkataan orang lain tanpa menyelidikinya.

Bagi ulama, keyakinan akan Allah dibangun atas dasar pembuktian. Bagi shufi, keyakinan akan Allah dibangun atas dasar dzauq ruhani dan kasyaf Ilahi. Ma'rifat dalam pandangan Dzun Nun al-Misri adalah pengetahuan hakiki tentang Tuhan. Menurutnya, ma'rifat hanya terdapat pada kaum shufi yang sanggup melihat Allah dengan hati sanubari mereka. Ma'rifat dipancarkan ke hati para shufi dengan pancaran cahaya suci Ilahi. ${ }^{1}$

Ma'rifat menurut Syeikh Ibnu Athaillah As-Sakandari, siapapun yang merenung secara mendalam akan menyadari bahwa semua makhluk sebenarnya menauhidkan Allah Swt. lewat tarikan nafas yang halus. Jika tidak, pasti mereka akan mendapat siksa. Pada

${ }^{1}$ Ibid, h. 261-262 
setiap zarah, mulai dari ukuran sub-atomis (kuantum) sampai atomis, yang terdapat di alam semesta terdapat rahasia nama-nama Allah. Dengan rahasia tersebut, semuanya memahami dan mengakui keesaan Allah. Allah Swt. telah berfirman,

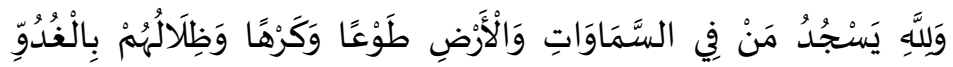

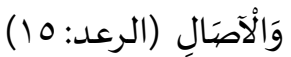

Hanya kepada Allah-lah sujud (patuh) segala apa yang di langit dan di bumi, baik dengan kemauan sendiri atau pun terpaksa (dan sujud pula) bayang-bayangnya di waktu pagi dan petang hari (QS Ar-Ra'd:15).]

Jadi, semua makhluk mentauhidkan Allah dalam semua kedudukan sesuai dengan rububiyah Allah serta sesuai dengan bentuk-bentuk ubudiyah yang telah ditentukan dalam mengaktualisasikan tauhid mereka. Lebih lanjut Syeikh mengatakan bahwa sebagian ahli makrifat berpendapat bahwa orang yang bertasbih sebenarnya bertasbih dengan rahasia kedalaman hakikat kesucian pikirannya dalam wilayah keajaiban alam malakut dan kelembutan alam jabarut.

Sementara sang salik, bertasbih dengan dzikirnya dalam lautan qolbu. Sang murid bertasbih dengan qolbunya dalam lautan pikiran. Sang Pecinta bertasbih dengan ruhnya dalam lautan kerinduan. Sang Arif bertasbih dengan sirr-nya dalam lautan alam gaib. Dan orang shiddiq bertasbih dengan kedalaman sirr-nya dalam rahasia cahaya yang suci yang beredar di antara berbagai makna Asmaasma dan Sifat-sifat-Nya disertai dengan keteguhan di dalam 
silih bergantinya waktu. Dan dia yang hamba Allah bertasbih dalam lautan pemurnian dengan kerahasian sirr-al-Asrar dengan memandang-Nya, dalam kebaqaan-Nya. ${ }^{1}$

\section{Ahwal}

Secara bahasa, ahwal merupakan jamak dari kata tunggal hal yang berarti keadaan sesuatu (keadaan rohani). Menurut Syeikh Abu Nashr as-Sarraj, haladalah sesuatu yang terjadi secara mendadak yang bertempat pada hati nurani dan tidak mampu bertahan lama, sedangkan menurut al-Ghazali,hal adalah kedudukan atau situasi kejiwaan yang dianugerahkan Allah kepada seseorang hamba pada suatu waktu, baik sebagai buah dari amal saleh yang mensucikan jiwa atau sebagai pemberian semata. Sehubungan dengan ini, Harun Nasution mendefinisikan hal sebagai keadaan mental, seperti perasaan senang, persaan sedih, perasaan takut, dan sebagainya.

Jika berpijak dari beberapa pendapat para shufi di atas, maka tidak ada perbedaan, yang pada intinya, hal adalah keadaan ruhani seorang hamba ketika hatinya telah bersih dan suci. Hal berlainan dengan maqam, hal tidak menentu datangnya, terkadang datang dan perginya berlangsung cepat, yang disebut lawaih dan ada pula yang datang dan perginya dalam waktu yang lama, yang disebut

\footnotetext{
1 http://sufiroad.blogspot.com/2010/08/tauhid-dan-marifatullah.html di akses tgl 21 februari 2013
} 
bawadih. ${ }^{1}$ Jika maqam diperoleh melalui usaha, akan tetapi hal bukan diperoleh melalui usaha, akan tetapi anugerah dan rahmat dari Allah Swt. Maqam sifatnya permanen, sedangkan hal sifatnya temporer sesuai tingkatan maqamnya. ${ }^{2}$ Sebagaimana halnya dengan maqamat, dalam penentuan hal juga terdapat perbedaan pendapat di kalangan sufi. Adapun al-hal yang paling banyak disepakati adalah al-muraqabah, al-khauf, ar-raja', ath-thuma'ninah, almusyahadah, dan al-yaqin. ${ }^{3}$ Penjelasan tentang ahwal tersebut adalah sebagai berikut:

\section{Muraqabah}

Muraqabah artinya merasa selalu diawasi oleh Allah Swt. sehingga dengan kesadaran ini mendorong manusia senantiasa rajin melaksanakan perintah dan menjauhi larangan-Nya.

Sesungguhnya manusia hakikinya selalu berhasrat dan ingin kepada kebaikan dan menjunjung nilai kejujuran dan keadilan, meskipun tidak ada orang yang melihatnya.

Kehati-hatian (mawas diri) adalah kesadaran. Kesadaran ini makin terpelihara dalam diri seseorang hamba jika meyakini bahwa Allah Swt. senantiasa melihat dirinya.

Syeikh Ahmad bin Muhammad Ibnu Al Husain Al Jurairy mengatakan, "Jalan kesuksesan itu dibangun di atas dua bagian.

\footnotetext{
${ }^{1}$ Ibid, h.262-263

2 Ali Anwar Yusuf, Studi Agama Islam Untuk Perguruan Tinggi, (Bandung: Pustaka Setia, 2003), h.200

${ }^{3}$ Tim Penyusun MKD IAIN Sunan Ampel, Akhlak...,h.263-264
} 
Pertama, hendaknya engkau memaksa jiwamu muraqabah (merasa diawasi) oleh Allah Swt. Kedua, hendaknya ilmu yang engkau miliki tampak di dalam perilaku lahiriahmu sehari-hari". 1

\section{Khawf}

Khauf adalah suatu sikap mental yang merasa takut kepada Allah karena kurang sempurna pengabdianya. Takut dan kawatir kalau Allah tidak senang kepadanya. Menurut Ghozali Khauf adalah rasa sakit dalam hati karena khawatir akan terjadi sesuatu yang tidak disenagi dimasa sekarang.

Menurut al Ghozali Khauf terdiri dari tiga tingkatan atau tiga derajat, di antaranya adalah:

1. Tingkatan Qashir (pendek), yaitu khauf seperti kelembutan perasaan yang dimiliki wanita, perasaan ini seringkali dirasakan tatkala mendengarkan ayat-ayat Allah dibaca.

2. Tingkatan Mufrith (yang berlebihan), yaitu khauf yang sangat kuat dan melewati batas kewajaran dan menyebabkan kelemahan dan putus asa, khauf tingkat ini menyebabkan hilangya kendali akal dan bahkan kematian, khauf ini dicela karena karena membuat manusia tidak bisa beramal.

3. Tingkatan Mu'tadil (sedang), yaitu tingkatan yang sangat terpuji, ia berada pada khauf qashir dan mufrith. ${ }^{2}$

1 http://httpahmadbudiyonoblogspotcom.blogspot.com/2012/04/pengetiandan-tahapan-maqamat-dan-ahwal.html di akses tgl 24/11/2012 pukul 22.56 ${ }^{2}$ Tim penyusun MKD IAIN Sunan Ampel, Akhlak..., h.266-267 
Rasulullah Saw. bersabda: "Apabila tubuh hamba menggigil karena takut kepada Allah Swt., dosa-dosanya berguguran seperti daun-daun yang berguguran dari pohon".

Abû al-Layts r.a. berkata, "Allah memiliki para malaikat di langit ketujuh. Mereka bersujud sejak Allah menciptakan mereka hingga hari kiamat. Mereka menggigil ketakutan karena takut kepada Allah Swt. Apabila hari kiamat tiba, mereka mengangkat kepala dan berkata, Mahasuci Engkau, kami menyembah-Mu dengan penyembahan yang sebenar-benarnya".

Itulah firman Allah Swt.: Mereka takut kepada Tuhan mereka yang di atas mereka dan melaksanakan apa yang diperintahkan (QS. an-Nahl [16]: 50). Yakni, mereka tidak berbuat maksiat kepada Allah sekejap mata pun.

Rasulullah Saw. bersabda, "Apabila tubuh hamba menggigil karena takut kepada Allah Swt., maka dosa-dosanya berguguran seperti daun-daun yang berguguran dari pohon." Dikisahkan bahwa seorang laki-laki tertambat hatinya kepada seorang perempuan. Perempuan itu keluar untuk suatu keperluan. Laki-laki itu ikut pergi bersamanya. Ketika mereka berduaan di padang sahara, sementara orang lain sudah tertidur, laki-laki itu mengungkapkan isi hatinya kepada perempuan tersebut: Perempuan itu berkata,"Lihatlah, semua orang sudah tertidur." Laki-laki itu senang mendengar kata-kata itu.

Dia mengira bahwa perempuan itu telah memberikan jawaban kepadanya. Lalu, dia berdiri dan mengelilingi kafilah. Dia mendapati orang-orang sudah tertidur. Lalu, dia kembali kepada 
perempuan itu dan berkata, "Benar, mereka telah tidur." Namun, perempuan itu bertanya, "Apa pendapatmu tentang Allah, apakah Dia tidur pada saat ini?" Laki-laki itu menjawab, "Allah Swt. tidak tidur. Dia tidak pernah terserang kantuk dan tidur". Perempuan itu berkata, "Zat yang tidak tidur dan tidak akan tidur selalu melihat kita walaupun orang lain tidak melihat kita. Karena itu, Allah lebih pantas untuk ditakuti." Akhirnya, laki-laki itu pun meninggalkan perempuan tadi karena takut kepada Sang Pencipta. Dia bertobat dan kembali ke kampung halamannya. Ketika dia meninggal, orangorang bemimpi melihatnya. Ditanyakan kepadanya, "Apa tindakan Allah kepadamu?" Dia menjawab, "Dia mengampuniku karena ketakutanku itu. Dengan demikian, terhapuslah dosa tersebut."1

\section{Rajā'}

Raja' dapat berarti berharap atau optimisme, yaitu perasaan senang hati karena menanti sesuatu yang diinginkan dan disenangi. Raja'atau optimisme ini telah ditegaskan dalam alQur'an:

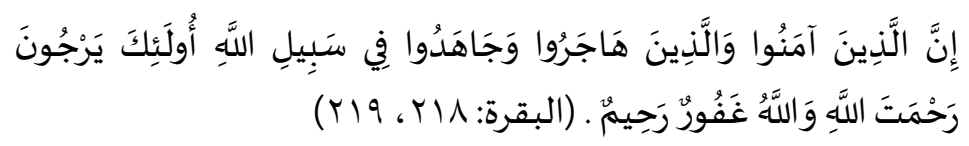

"Sesungguhnya orang-orang yang beriman, orang-orang yang berhijrah dan berjihad di jalan Allah, mereka itu mengharapkan rahmat Allah, dan Allah Maha Pengampun lagi Maha Penyayang”.(Al-Baqarah: 218).

\footnotetext{
${ }^{1}$ http://sufiroad.blogspot.com/2010/12/sufi-road-takut-kepada-allah.html di akses tgl 21 februari 2013
} 
Orang yang harapan dan penantiannya mendorongnya untuk berbuat ketaatan dan mencegahnya dari kemaksiatan, berarti harapannya benar. Sebaliknya, jika harapannya hanya angan-angan, semenatara ia sendiri tenggelam dalam lembah kemaksiatan, harapannya sia-sia.

Raja' menurut tiga perkara, yaitu:

1. Cinta kepada apa yang diharapkannya.

2. Takut bila harapannya hilang.

3. Berusaha untuk mencapainya.

Raja' yang tidak dibarengi dengan tiga perkara itu hanyalah ilusi atau hayalan. Setiap orang yang berharap adalah juga orang yang takut (khauf). Orang yang berharap untuk sampai di suatu tempat tepat waktunya, tentu ia takut terlambat. Dan karena takut terlambat, ia mempercepat jalannya. Begitu pula orang yang mengharap rida atau ampunan Allah, diiringi pula dengan rasa takut akan siksaan Allah. ${ }^{1}$

\section{Țuma'ninah}

Tuma'ninah adalah rasa tenang, tidak ada rasa was-was atau khawatir, tak ada yang dapat mengganggu perasaan dan pikiran, karena ia telah mencapai tingkat kebersihan jiwa yang paling tinggi. Seseorang yang telah mencapai tingkatan thuma'ninah, ia telah kuat akalnya, kuat imannya dan ilmunya serta bersih ingatannya. Jadi, orang tersebut merasakan ketenangan, bahagia, tentram dan ia dapat

\footnotetext{
${ }^{1}$ Rosibon Anwar dan Mukhtar Solihin, Ilmu..., h.75-76
} 
berkomunikasi langsung dengan Allah. Thuma'ninah dibagi menjadi tiga tingkatan. Pertama, ketenangan bagi kaum awam. Ketenangan ini didapatkan ketika seorang hamba berzikir, mereka merasa tenang karena buah dari berzikir adalah terkabulnya doa-doa. Kedua, ketenangan bagi orang-orang khusus. Mereka di tingkat ini merasa tenang karena mereka rela, senang atas keputusan Allah, sabar atas cobaan-Nya, ikhlas dan takwa. Ketiga, ketenangan bagi orang-orang paling khusus. Ketenangan di tingkat ini mereka dapatkan karena mereka mengetahui bahwa rahasia-rahasia hati mereka tidak sanggup merasa tentram kepada-Nya dan tidak bisa tenang kepadaNya, karena kewibawaan dan keagungan-Nya. ${ }^{1}$

\section{Uns}

Uns (suka cita) dalam pandangan shufi adalah sifat merasa selalu berteman, tak pernah merasa sepi. Dalam keadaan seperti ini, seorang sufi merasakan tidak ada yang dirasa, tidak ada yang diingat, tidak ada yang diharap kecuali Allah. Segenap jiwa terpusat bulat kepada-Nya, sehingga ia seakan-akan tidak menyadari dirinya lagi dan berada dalam situasi hilang kesadaran terhadap alam sekitarnya. Situasi kejiwaan seperti itulah yang disebut al-Uns. Ada sebuah ungkapan yang menggambarkan al-Uns sebagai berikut: "Ada orang yang merasa sepi dalam keramaian. Ia adalah orang yang selalu memikirkan kekasihnya, sebab sedang dimabuk cinta, seperti halnya sepasang pemuda dan pemudi. Ada pula orang yang bising

${ }^{1}$ Tim penyusun MKD IAIN Sunan Ampel, Akhlak..., h.269-270 
dalam kesepian. Ia adalah orang selalu memikirkan atau merencanakan tugas pekerjaannya semata-mata. Adapun engkau selalu berteman di manapun berada. Alangkah mulianya engkau berteman dengan Allah. Artinya engkau selalu berada dalam pemeliharaan Allah.

Seorang hamba yang merasakan Uns dibedakan menjadi tiga kondisi. Pertama, seorang hamba yang merasakan suka cita berzikir mengingat Allah dan merasa gelisah di saat lalai. Merasa senang di saat berbuat ketaatan dan gelisah berbuat dosa. Kedua, seorang hamba yang merasa senang dengan Allah dan gelisah terhadap bisikan-bisikan hati, pikiran dan segala sesuatu selain Allah yang akan menghalanginya untuk dekat dengan Allah. Ketiga, yaitu kondisi yang tidak lagi melihat suka citanya karena adanya wibawa, kedekatan, kemuliaan dan mengagungkan disertai dengan suka cita. ${ }^{1}$

\section{Mushāhadah}

Musyahadah secara harfiah adalah menyaksikan dengan mata kepala. Secara terminologi, tasawuf adalah menyaksikan secara jelas dan sadar apa yang dicarinya (Allah) atau penyaksian terhadap kekuasaan dan keagungan Allah. Seorang shufi telah mencapai musyahadah ketika sudah merasakan bahwa Allah telah hadir atau Allah telah berada dalam hatinya dan seseorang sudah tidak menyadari segala apa yang terjadi, segalanya tercurahkan pada yang satu, yaitu Allah, sehingga tersingkap tabir yang menjadi

\footnotetext{
${ }^{1}$ Ibid, h.270-271
} 